\title{
Study on Construction Organization Measures of Transmission Line
}

\author{
Chen LIU ${ }^{1, a}$, Guang-Rui TANG ${ }^{2, b}$, Yu-Jing HAO ${ }^{3, c}$, Fei PENG ${ }^{4, d}$ \\ ${ }^{1-4}$ China Electric Power Research Institute, Beijing, 100055, China

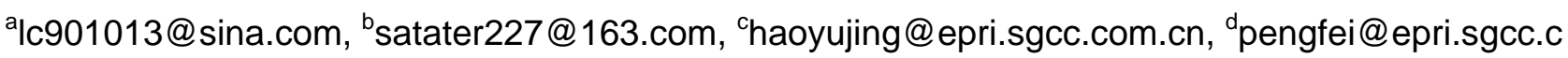 \\ om.cn
}

Keywords: Transmission line, Construction organization, Mechanized construction, Construction process

\begin{abstract}
With the improvement of mechanical construction level of China, the organization planning of construction equipment in the mechanical construction is more and more important, while the construction organization measures of mechanized construction for transmission line are lacks of related research at present. In this paper, mechanization construction organization measures for transmission lines are studied according to the construction process, typical construction organization scheme of each process is proposed. Mechanization construction organization measures of transmission line improves the construction level of the transmission line mechanization, decreases the intensity of labor, and ensures the construction safety, which has definite guiding significance to achieve the whole process of mechanized construction of transmission line.
\end{abstract}

\section{Introduction}

In traditional mode, transmission line engineering construction is mainly based on human power, supplemented by machinery equipment, the construction mechanization level is low, which causes high intensity of labor, low efficiency of construction and high risk of operation, some construction methods fail to fully consider the requirements of environmental protection. To meet the requirements of the whole process of mechanical construction, reduce manual input and operational risk, reasonable using of construction organization measures is conducive to further enhance the quality and the efficiency of engineering construction, and promote economic, environmental and social benefits.

The traditional construction organization model has not provided special mechanized construction team, lacks of mechanized construction organization, resulting in a large waste of resources. Using mechanical replace artificial improves labor efficiency, reduces the labor intensity of workers, it is more able to adapt to the construction site. Set up a professional team, exert mechanical properties, which can ensure that the whole project is carried out in a continuous and balanced manner.

\section{Classification and Characteristics of Construction Organization Method}

Productivity determines production relation, mechanized construction improves productivity, so that construction organization makes corresponding adjustment. Conventional mechanical construction organization methods of transmission line are mainly divided into four types: flow operation method, parallel operation method, network planning method and sequential planning method.

The flow operation method of overhead transmission line engineering is a method that divided the transmission line engineering into several construction segments according to the process and working procedure requirements, and set a professional construction team entered the construction segment operations according to certain construction sequence.

Specialized construction flow operation method meets the basic requirements of the construction mechanization, which is the preferred method of mechanized construction organization. 


\section{Construction Organization Mode of Flow Operation Method in Each Working Procedure of Transmission Line}

In the process of mechanized construction, construction measures coordinate with construction machinery reasonable and economical, ensures that the whole construction project carried out continuously in a balanced manner, and give full play to the mechanical properties, so that the whole construction organization design can be better completed.

According to the construction process, the whole process of mechanical construction of transmission line is mainly divided into seven working procedure: temporary road construction, material transportation, foundation construction, concrete pouring, tower erection, stringing construction and grounding construction.

Temporary Road Construction. By founding a professional construction team, the construction unit chooses construction equipment according to the construction of content, combined with the design drawings and site conditions to meet the needs of subsequent construction. Using specialized equipment, construct road at one time. According to the different terrain conditions, temporary road construction should meet the following requirements:

Flat, hilly area: The access road surface should be clean, leveling and compaction, and the subgrade should be widening, in order to meet the need of access of material and heavy machinery.

River network area: Use prefabricated steel bridge to bridging. Mostly build construction cofferdam for construction road in fish ponds and shrimp ponds.

Mountain area: Use cableway transportation instead of roads construction, it improves transport efficiency, and reduces the destruction of vegetation.

Personnel organization of temporary road construction is shown in table 1.

Table 1 Temporary road construction personnel organization statistical table

\begin{tabular}{|c|c|c|c|c|c|}
\hline \multirow{2}{*}{ Process } & & \multirow{2}{*}{ Job content } & \multicolumn{3}{|c|}{ Construction } \\
\hline & & & Total & $\begin{array}{l}\text { Technical } \\
\text { worker }\end{array}$ & $\begin{array}{l}\text { General } \\
\text { worker }\end{array}$ \\
\hline \multirow{5}{*}{$\begin{array}{l}\text { Temporary road } \\
\text { construction }\end{array}$} & & Commander & 1 & 1 & \\
\hline & & Technical worker & 2 & 2 & \\
\hline & & Excavator & 2 & & 2 \\
\hline & $\begin{array}{l}\text { Labour } \\
\text { worker }\end{array}$ & Loader & 2 & & 2 \\
\hline & & Cableway erection & 16 & 4 & 12 \\
\hline
\end{tabular}

Material Transportation. The transport team is responsible for the transportation of base steel; Tank truck, concrete pump truck, trailer pump are leased from commercial concrete station or select and purchase by the construction unit.

The transport team is responsible for the transportation and the loading and unloading of tower material. The equipment of tower erection is transported by cableway. Cableway is qualified with the transportation of the longest and the heaviest piece of tower material.

The transport team is responsible for the transportation of guide rope, pull blade, appliance, etc.

Professional team is responsible for the transportation of special equipment such as multi rotor UAV, powered parachute, airship, etc.

Personnel organization of material transportation construction is shown in table 2. 
Table 2 Material transportation construction personnel organization statistical table

\begin{tabular}{|c|c|c|c|c|c|}
\hline \multirow{2}{*}{ Process } & \multirow{2}{*}{\multicolumn{2}{|c|}{ Job content }} & \multicolumn{3}{|c|}{ Construction } \\
\hline & & & Total & $\begin{array}{c}\text { Technical } \\
\text { worker }\end{array}$ & $\begin{array}{l}\text { General } \\
\text { worker }\end{array}$ \\
\hline \multirow{3}{*}{$\begin{array}{c}\text { Material } \\
\text { transportation }\end{array}$} & & Commander & 1 & 1 & \\
\hline & & Technical worker & 2 & 2 & \\
\hline & $\begin{array}{c}\text { Labou } \\
\text { r } \\
\text { worker }\end{array}$ & Personnel of loading and unloading & 16 & 4 & 12 \\
\hline
\end{tabular}

Foundation Construction. Excavator is used for the excavation backfill foundation, the construction team should bring along their own excavator or by social lease; Diving drill rig is used for the pile foundation, the construction team should bring along their own rig; Anchor drilling rig is used for the anchor foundation, the construction team should bring along their own anchor drilling rig, or provided by the construction unit; Rotating drill is used for the excavation foundation and pile foundation, using social lease.

Personnel organization of foundation construction is shown in table 3.

Table 3 Foundation construction personnel organization statistical table

\begin{tabular}{|c|c|c|c|c|c|}
\hline \multirow{2}{*}{ Process } & & \multirow{2}{*}{ Job content } & \multicolumn{3}{|c|}{ Construction } \\
\hline & & & Total & $\begin{array}{c}\text { Technical } \\
\text { worker }\end{array}$ & General worker \\
\hline \multirow{5}{*}{$\begin{array}{l}\text { Foundation } \\
\text { construction }\end{array}$} & & Commander & 1 & 1 & \\
\hline & & Technical worker & 2 & 2 & \\
\hline & & Rotating drill rig & 2 & & 2 \\
\hline & $\begin{array}{l}\text { Labour } \\
\text { worker }\end{array}$ & Excavator & 6 & & 6 \\
\hline & & Manual hole digging & 8 & & 8 \\
\hline
\end{tabular}

Concrete Pouring. In the whole process of mechanical construction mode, the use of complete sets of equipment to replace manpower construction improves construction efficiency. Centralized processing of steel reinforcement cage in material station implements engineering processing, protecting the effects from weather. The use of mixing station to replace mechanical stirring reduces the manpower to implement the standardization construction of the flow operation.

Personnel organization of concrete pouring construction is shown in table 4. 
Table 4 Concrete pouring construction personnel organization statistical table

\begin{tabular}{|c|c|c|c|c|c|}
\hline \multirow{2}{*}{ Process } & \multirow{2}{*}{\multicolumn{2}{|c|}{ Job content }} & \multicolumn{3}{|c|}{ Construction } \\
\hline & & & Total & $\begin{array}{c}\text { Technical } \\
\text { worker }\end{array}$ & $\begin{array}{l}\text { General } \\
\text { worker }\end{array}$ \\
\hline & & Commander & 1 & 1 & \\
\hline & & Monitoring mix proportion, catheter & 2 & 1 & 1 \\
\hline & Commercia & & & & \\
\hline & $\begin{array}{c}\text { l concrete } \\
\text { pouring }\end{array}$ & Monitoring basic geometry size & 2 & 1 & 1 \\
\hline & & Concrete vibrator & 2 & 2 & \\
\hline & & Other & 8 & & 8 \\
\hline & & Commander & 1 & 1 & 0 \\
\hline & & Monitoring mix proportion & 1 & 1 & 0 \\
\hline & & Stirring, generator handling & 2 & 2 & 0 \\
\hline \multirow[t]{9}{*}{ Concrete pouring } & & Supply of cement & 3 & 0 & 3 \\
\hline & Site & Supply of sand & 6 & 0 & 6 \\
\hline & pouring & Supply of stones & 8 & 0 & 8 \\
\hline & & Supply of water & 2 & 0 & 2 \\
\hline & & Transport of concrete & 4 & 0 & 4 \\
\hline & & Concrete vibrator & 4 & 2 & 2 \\
\hline & & Monitoring basic geometry size & 3 & 2 & 1 \\
\hline & & n stripping and backfilling & 14 & 2 & 12 \\
\hline & & servation and security guard & 2 & 1 & 1 \\
\hline
\end{tabular}

Tower Erection. The tower construction team for construction is divided into three groups: ground assembly, tower hoisting and tower maintenance. According to the actual situation, use ground rocker pole, ground double flat arm pole, internal suspension external pull pole and crane to construct tower.

Personnel organization of tower erection construction is shown in table 5. 
Table 5 Tower erection construction personnel organization statistical table

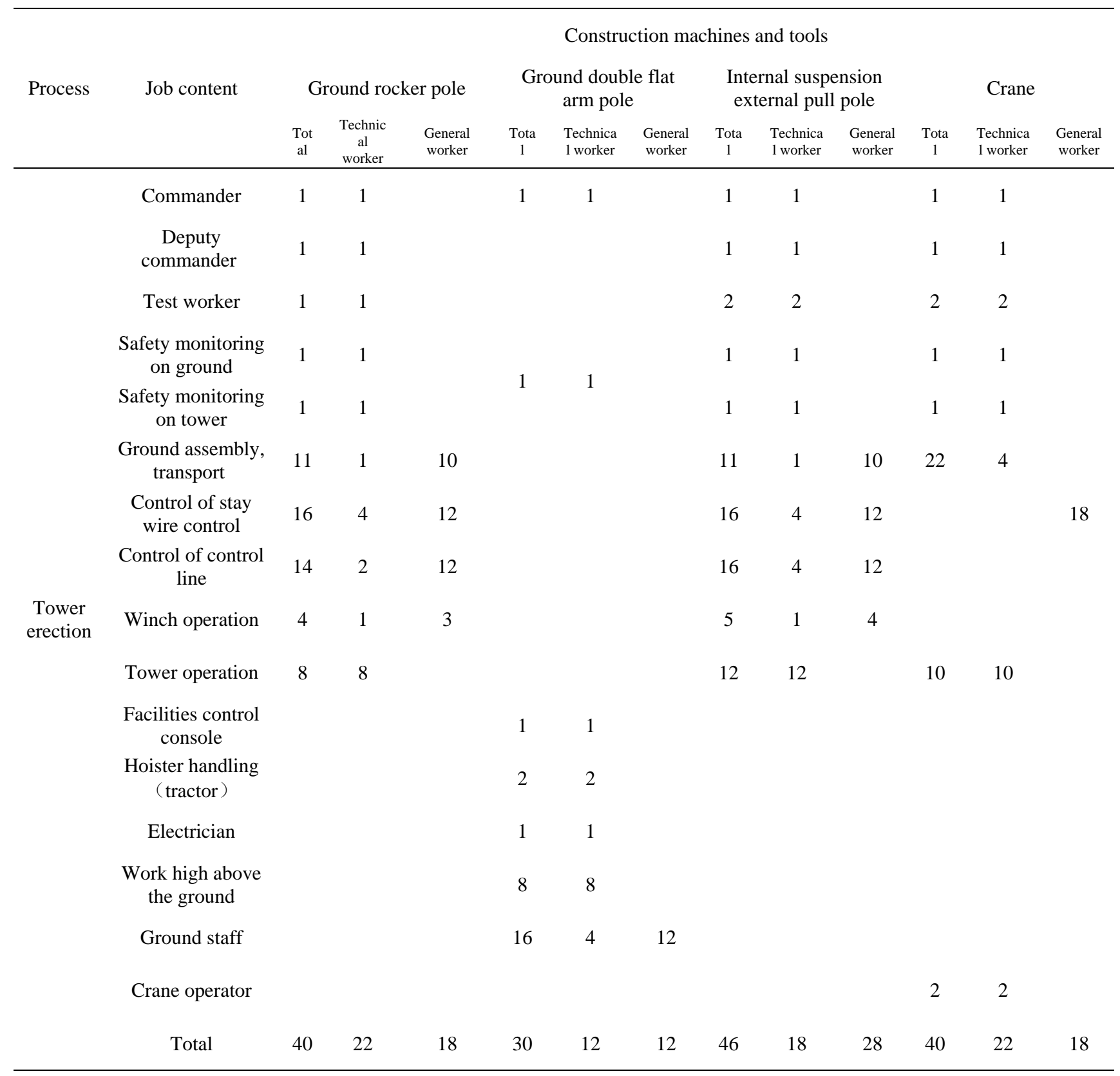

Stringing Construction. Working procedure of ground construction is divided into expand guide rope, expand ground wire, tense line, put line, balance hanging line, installation of attachments, installation of wire jumper, etc.

Multi rotor UAV is recommended for expand the primary guide rope, which implement the expanding of the whole process of stringing construction, improving the construction efficiency.

Personnel organization of stringing construction is shown in table 6. 
Table 6 Stringing construction personnel organization statistical table

\begin{tabular}{|c|c|c|c|c|}
\hline \multirow{2}{*}{ Process } & \multirow{2}{*}{ Job content } & \multicolumn{3}{|c|}{ Construction } \\
\hline & & Total & Technical worker & General worker \\
\hline & Erection and demolition of spanning frame & 20 & 4 & 16 \\
\hline & Expand guide rope and hauling rope & 30 & 5 & 25 \\
\hline & Tension field & 24 & 8 & 16 \\
\hline & Traction field & 16 & 4 & 12 \\
\hline & Communication, line protection along the line & 18 & 5 & 13 \\
\hline & Ground wire crimping & 6 & 2 & 4 \\
\hline & Conductor crimping & 14 & 2 & 12 \\
\hline \multirow[t]{8}{*}{$\begin{array}{l}\text { Stringing } \\
\text { construction }\end{array}$} & Sag observation of ground wire & 6 & 2 & 4 \\
\hline & Sag observation of conductor & 8 & 4 & 4 \\
\hline & Balance hanging line & 28 & 8 & 20 \\
\hline & Installation of ground wire attachments & 6 & 2 & 4 \\
\hline & Installation of conductor attachments & 18 & 6 & 12 \\
\hline & Installation of spacer & 15 & 3 & 12 \\
\hline & Installation of wire jumper & 25 & 5 & 20 \\
\hline & Maintenance, alignment & 15 & 3 & 12 \\
\hline
\end{tabular}

Grounding Construction. The time of ground construction is short, it should be grounding in time after the excavation, which could avoided the collapse of ground trench, so that the ground construction is more easier to implement the flow operation after the foundation of backfilling.

Set up a specialized construction team, use specialized equipment to ground construction, which improves construction efficiency.

It is recommend to use small excavators and chain trencher to excavate ground trench in flat area; Use small excavators to excavate ground trench in hilly area; Use directional drilling rig and vertical drilling rig to excavate ground trench in non-excavation laying ground construction.

Personnel organization of grounding construction is shown in table 7.

Table 7 Grounding construction personnel organization statistical table

\begin{tabular}{|c|c|c|c|c|c|}
\hline Process & Job content & $\begin{array}{c}\text { Artificial } \\
\text { excavation }\end{array}$ & $\begin{array}{l}\text { Excavators } \\
\text { excavation }\end{array}$ & $\begin{array}{l}\text { Chain } \\
\text { trencher }\end{array}$ & $\begin{array}{l}\text { Directional drilling } \\
\text { rig }\end{array}$ \\
\hline \multirow{3}{*}{$\begin{array}{l}\text { Grounding } \\
\text { construction }\end{array}$} & Principal & & & & \\
\hline & $\begin{array}{l}\text { Technical worker } \\
\text { (Welding) }\end{array}$ & & & & \\
\hline & Labour worker & 10 & 4 & 2 & 2 \\
\hline
\end{tabular}

\section{Summary}

(1) Through the selection of the basic method of construction organization, the construction organization mode suitable for the whole process of mechanized construction of transmission line is 
determined. The Flow operation method is used in the construction section (Group), which balanced and optimized the construction capacity, ensures the continuous balance on the whole construction project.

(2) Introduce the construction organization characteristics in each process of transmission line construction, considering the whole process of mechanization construction, it can be divided into seven working procedure: temporary road construction, material transportation, foundation construction, concrete pouring, tower erection, stringing construction and grounding construction. Optimized the construction organization, and typical construction organization scheme of each process are put forward. Mechanization construction organization measures of transmission line improves the efficiency of mechanical construction, reduces the manpower, ensures the safety of the construction, which is practical for the applications of the whole process of mechanized construction of transmission line in engineering.

\section{Acknowledgement}

This research was financially supported by the Science and Technology Project of China State Grid Corp. The number of the project is GC71-15-042.

\section{References}

[1] Li CHENG, Xiao-Ping WANG, Zhi-Qing HUANG, et al. Optimizing of Construction Organization Design [J]. Architecture Technology, 2007, 38 (4): 311-312.

[2] Hua-Li YIN. Analysis on Effects of the Construction Organization to the Construction Item Cost [D]. Shandong University, 2007.

[3] A Belout, C Gauvreau. Factors Influencing Project Success: The Impact of Human Resource Management [J]. International Journal of Project Management, 2004, 22 (1): 1-11.

[4] Ming LAN. A Study on the Optimal Measures of Construction Organization Design [D]. Beijing Forestry University, 2010.

[5] Hao PANG. UHV DC Transmission Line Construction Organization Design Optimization [D]. North China Electric Power University, 2013.

[6] K Hyari, K Elrayes. Optimal Planning and Scheduling for Repetitive Construction Projects [J]. Journal of Management in Engineering, 2006, 22 (1): 11-19. 